\title{
The effect of storage to optical properties in case of two apple fruit varieties
}

\author{
El Shal, A. M. ${ }^{1,2}$, Riczu, P. ${ }^{1}$, Nagy, A. ${ }^{1}$, Sulyok, E. ${ }^{1}$, Tamás, J. ${ }^{1}$, Szabó, Z. ${ }^{3}$ \& Nyéki, J. ${ }^{3}$ \\ ${ }^{1}$ University of Debrecen, Centre for Agricultural Sciences and Engineering, Faculty of Agricultural and Food \\ Sciences and Environmental Management, Institute of Water and Environmental Management, \\ H-4032 Debrecen, Böszörményi str. 138, Hungary, \\ ${ }^{2}$ Zagazig University, Faculty of Agriculture, Department of Agricultural Engineering, \\ 44511 Zagazig, Egyptamelshal@zu.edu.eg \\ ${ }^{3}$ University of Debrecen, Institute for Research and Development, \\ H-4032 Debrecen, Böszörményi str. 138, Hungary
}

\begin{abstract}
Summary: The keeping quality of fruits is a very important factor in storage point of view, since it could be elongated the consumption time of fruits. In many cases the storage may be necessary, e.g. in short time it is not able to market due to the rich harvest, or all fruits could sell in markets throughout the year. The keeping quality of various fruit species is greatly different; moreover it could be observed some differences between the varieties as well. In our research, we have investigated the spectral properties of the external surface and flesh of two ripe apple varieties - Jonagored and Granny Smith - before and after storage (about $3^{\circ} \mathrm{C}$ and about three weeks). The hyperspectral investigation was carried out with AvaSpec-2048 Fiber Optic Spectrometer. The experimental results represented the differences between healthy and chilling injured apple fruits. Furthermore, some indices were created to given countenance to the spectral differences.
\end{abstract}

Key words: apple fruit, spectrometer, spectral profile, reflectance, vegetation indices

\section{Introduction}

The total apple production of the world ranges is more than 69 million tonnes. Regarding the harvested area, Asia has a leading role as about $66 \%$ of apple is produced here. Presently, in Hungary about 34000 hectares of apple orchards can be found, from which approximately 500 thousand tonnes of fruits could be harvested (FAOSTAT, 2010), although in the last period the production was reduced (Gonda \& Apati, 2011).

Sometimes, the big amount of harvested fruits must be stored due to in absence of market and the fruit quality could be preserved with correct storage method and after the storage could increase the economic profit of fruit production. But often, chilling injury could cause the most common disorders by industry. It is a physiological damage to fruit cell membranes that may occur at any time due to harmful environmental conditions during the growing season, transportation, distribution, or storage, at the retail store, or even in a home refrigerator. Membrane damage is often followed by a cascade of secondary effects, such as ethylene production, an increase in respiration, a decrease in photosynthesis, and an alteration of cellular structure causing the fruits to be more susceptible to diseases. This injury first appears as a very slight browning discoloration of the flesh, sometimes accompanied by core browning ( $E l$
Masry et al., 2009). The skin of fruits content of chlorophylls, carotenoids and anthocyanins as well as their proportions determine fruit color and appearance (Saure, 1990; Abbott, 1999) and serve as markers of quality (Merzlyak et al., 2003), but in many cases the chilling injury disorder of apples can progress quickly to make the fruit unmarketable (Reay, 1999; Watkins \& Jackie Nock, 2004). Some internal symptoms and external defects could be detected by remote sensing methods in visible (VIS) and near infrared (NIR) ranges. Pen et al. (1985) judged good and bruised peeled apple tissue by the computed a special distance measurement (Mahalanobis distances) at 16 wavelengths (equally spaced between 350 and $700 \mathrm{~nm}$ ). Upchurch et al. (1990) used a wider range (400-1000 $\mathrm{nm}$ ) to detect bruised and non-bruised areas on whole 'Red Delicious' apples. For the objective result some vegetation indices are available to detecting physiological changes during the life of plant or fruits, or after the storage, respectively. The leaf chlorophyll content is closely related to plant stress and senescence (Hendry et al., 1987; Merzlyak \& Gitelson, 1995). Due to the senescent of leaves the chlorophyll content is deceased. One of the oldest, most well known and most frequently used vegetation index is the Normalized Difference Vegetation Index (NDVI) by Rouse et al. (1973), which use of the highest absorption and reflectance regions of chlorophyll make it robust over a wide range of conditions. The Simple 
Ratio (SR) index is another old and well known vegetation index, which is similar to the NDVI (Jordan, 1969). In case of very high spectral resolution reflectance data, such as from hyperspectral sensors, could be used the Red Edge Normalized Difference Vegetation Index $\left(\mathrm{NDVI}_{705}\right)$ and the Modified Red Edge Simple Ratio $\left(\mathrm{mSR}_{705}\right)$ indices. These indexes are more sophisticated measures of general quantity and vigor of green vegetation than the broadband greenness vegetation indexes. A third greenness vegetation index is the Modified Red Edge Normalized Difference Vegetation Index $\left(\mathrm{mNDVI}_{705}\right)$, which incorporated a correction for leaf specular reflection. These vegetation indices differ from the NDVI by using bands along the red edge, instead of the main absorption and reflectance peaks (Sims \& Gamon, 2002).

The plant senescent and fruit storage injuries could be investigated by several indices as well. The Plant Senescence Reflectance Index (PSRI) is designed to maximize the sensitivity of the index to the ratio of bulk carotenoids (for example, alpha-carotene and betacarotene) to chlorophyll (Merzlyak et al., 1999). The Browning Reflectance Index could provide information about senescent of leaves and/or ripening of fruits too (Chivkunova et al., 2001).
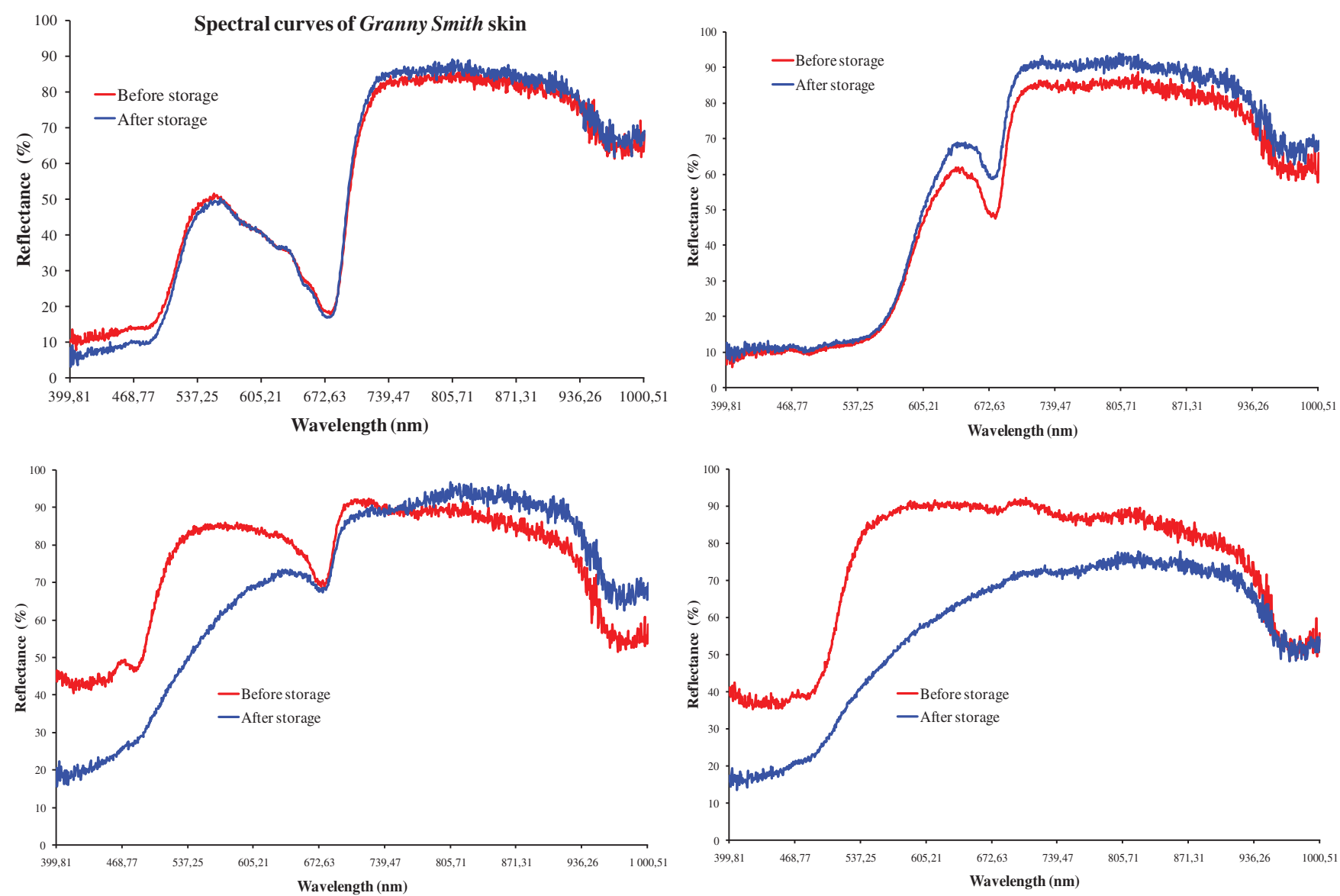

\section{Materials and methods}

In our experiment we examined the spectral characteristic of the peel and flesh of two apple varieties to assessment the effect of injury during the chilling storage. We have measured and evaluated the spectral differences between the fruits. The Jonagored (Golden Delicious x Jonathan) is one of the most dark red mutation of Jonagold. The fruit has bright red skin and sweet, juicy, aromatic flesh. The other variety was the Granny Ramsey Smith. The fruit has hard, light green skin and a crisp, juicy flesh.

First, we measured fresh, healthy fruits without symptoms and damages (which cut equal slices), then we put the samples into the refrigerator to simulated the effect of cold storage. The chilling storage was taken more than 3 weeks under $3{ }^{\circ} \mathrm{C}$. After storage we repeated the spectral measurement.

The reflectance spectra were measured by AvaSpec 2048 Fiber Optic Spectrometer within 400-1000 nm interval. The AvaSpec 2048 system consists of a spectrometer (detector) and connected by an $8 \mu \mathrm{m}$ core diameter fiber optic standard AvaLight-HAL halogen light source. The light source has about $1 \mu$ Watt light energy input to result the permanent light intensity in the whole measure range. The accurate measurement was provided by a special spectral sampling

Figure 1. Changes of spectral curves due to the chilling storage 
back box, since the samples were isolated from the variable external light.

Before the spectral measurement begin, the AvaSpec 2048 Spectrometer had to be calibrated by white and dark references. The special type of reference unit is WS-2 reference tiles, was made out of white diffuse PTFE (polytetrafluoroethylene) based material, meeting the highest demands with regard to high grade diffuse reflectance. In case of calibration the distance of the reflection probe and reference tiles, thus the samples were $3 \mathrm{~cm}$.

We processed the spectral data in the AvaSoft USB2, which is the own software of AvaSpec 2048 Spectrometer and Microsoft Office Excel ${ }^{\mathrm{TM}}$. Some parameters could be investigated based on spectral curves in the visible (VIS) and near infrared (NIR) ranges to detect the chilling injury of fruits during the storage.

\section{Results and discussion}

The characteristic of reflectance curves of both fruit varieties were followed form the absorption properties of fruit tissues. Depending on the amount of anthocyanin content, the spectral curves were different at 450-570 nm wavelength intervals. The peel of Granny Smith variety consisted more chlorophyll, than Jonagored, thus increased the reflectance in lower wavelength range in case of Granny Smith. The reflectance values on valley of spectral profiles at $677 \mathrm{~nm}$ simulated the absorption of chlorophyll in the red range; as well as thanks to the more red pigments the reflectance values were higher on the valley in case of Jonagored (Figure 1). All of greenness indices $\left(\mathrm{NDVI}_{705}, \mathrm{mNDVI}_{705}\right.$, and $\mathrm{mSR}_{705}$ ) were confirmed the chlorophyll degradation on the skin during the storage. We did not find significant change on chlorophyll content after chilling storage.

The Granny Smith flesh contained chlorophyll as well, which could be seen chlorophyll absorption valleys at 677 $\mathrm{nm}$. The lower reflectance values in the visible range shows decreasing of anthocyanin in the flesh.

In order to numerically observe the effect of chilling storage and browning of fruits were created indices from the reflectance values at given wavelengths. There is a close correlation between the Plant Senescence Reflectance Index (PSRI) and Browning Reflectance Index (BRI) as well as plant fruit ripening, fruit diseases affecting or leaf senescent. PSRI and BRI are defined by the following equations:

$$
\text { PSRI }=\frac{\rho_{680}-\rho_{500}}{\rho_{750}} \quad B R I=\frac{1 / \rho_{550}-1 / \rho_{700}}{\rho_{750}}
$$

The results show that these indices were higher values after storage in the most cases due to the brownish oxidation. The indices are appropriate for examined the browning of the flesh based on the spectral characteristic of the peel. The BRI of Jonagored skin was lower after storage than before storage. The BRI is not directly applicable for red-coloured apple fruit, since the presence of anthocyanins in their peel causes a significant decrease of $\mathrm{R}_{550}$ (Merzlyak \& Chivkunova 2000) interfering with the browning pigment assessment (Figure 2).

We have created a new reflectance index (SERI), which numerically shows the effect of storage. The results were similar to the PSRI ns BRI, since the values of after storage were higher in all of cases (Figure 2). The SERI was calculated by the following equation:

$$
S E R I=\frac{\rho_{675}-\rho_{470}}{\rho_{675}+\rho_{470}}
$$

The water content of the flesh was decreased during the storage, which could show another index. The Water Band Index (WBI) is sensitive to changes in fruit or canopy water status. The WBI could be calculated from $\mathrm{R}_{900}$ and $\mathrm{R}_{970}$ in the NIR region.

\section{Conclusion}

The effect of cold storage cause chilling injuries for the internal skin and/or the external flesh of fruits. Developed hyperspectral tools and methods could give opportunity to support a nondestructive technique for assessing the postharvest quality of fruits. These techniques would be beneficial to correctly classify them in different quality
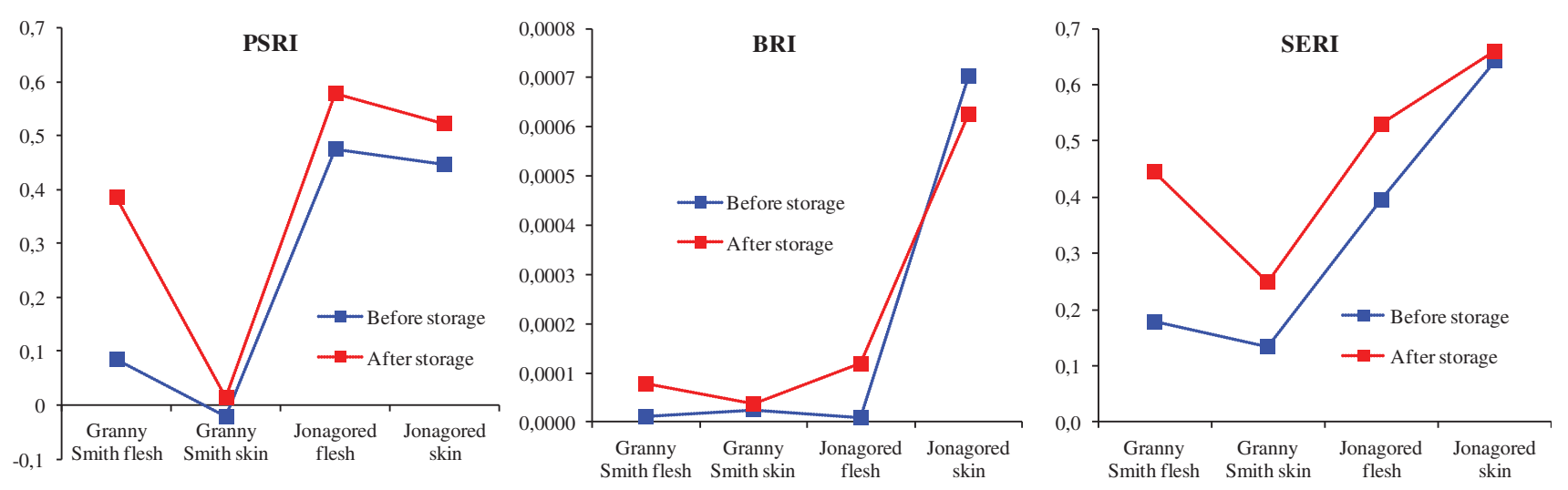

Figure 2. The created indices to detecting the effect of chilling storage 
levels. Further experiments are needed to find correlation between external chilling defect and internal browning of fruits to select the highest quality of fruits after storage.

\section{Acknowledgment}

This study is funded by TECH_08-A3/2-2008-0373 and TECH_08-A4/2-2008-0138 projects.

\section{References}

Abbott, J.A. (1999): Quality measurement of fruit and vegetables. Postharvest Biology and Technology. 15: 207-225.

Chivkunova, O.B., Solovchenko, A.E., Sokolova, S.G., Merzlyak, M.N., Reshetnikova, IV. \& Gitelson AA (2001): Reflectance Spectral Features and Detection of Superficial Scaldinduced Browning in Storing Apple Fruit. Journal of Russian Phytopathological Society. 2: 73-77.

El, Masry, G., Wang, N., Vigneault, C. (2009): Detecting chilling injury in Red Delicious apple using hyperspectral imaging and neural networks. Postharvest Biology and Technology. 52: 1-8.

FAOSTAT (2010): Food and agriculture organization of the United Nations for a world without hunger. http://faostat.fao.org/site/567/ default.aspx\#ancor. Web site visited on April 27, 2012.

Gonda I, Apáti F (2011): Present and future of apple growing in Hungary (Almatermesztésünk helyzete és jövőbeni kilátásai). [In. Tamás J (eds.): Almaültetvények vízkészlet-gazdálkodása.] Debreceni Egyetem, AGTC, Kutatási és Fejlesztési Intézet, Kecskeméti Főiskola, Kertészeti Főiskolai Kar. 13-25 p.

Hendry, G.A.F., Houghton, J.D., Brown, S.B. (1987): The degradation of chlorophyll-A biological enigma. New Phytologist. 107: 255-302.

Jordan, C.F. (1969): Derivation of leaf area index from quality of light in the forest floor. Ecology. 50: 663-666.

Merzlyak, M.N. \& Chivkunova, O.B. (2000): Light stress induced pigment changes and evidence for anthocyanin photoprotection in apple fruit. Journal of Photochemistry and Photobiology B. 55 (23): $154-162$

Merzlyak, M.N., Gitelson, A.A. (1995): Why and what for the leaves are yellow in autumn? On the interpretation of optical spectra of senescing leaves (Acer platanoides L.). Journal of Plant Physiology. 145: 315-320.

Merzlyak, M.N., Gitelson, A.A., Chivkunova, O.B. \& Rakitin, V.Y. (1999): Non-destructive Optical Detection of Pigment Changes During Leaf Senescence and Fruit Ripening. Physiologia Plantarum. 106: 135-141.

Merzlyak, M.N., Solovchenko, A. \& Gitelson, A.A. (2003): Reflectance spectral features and non-destructive estimation of chlorophyll, carotenoid and anthocyanin content in apple fruit. Postharvest Biology and Technology. 27: 197-212.

Pen, C.L., Bilanski, W.K. \& Fuzzen, D.R. (1985): Classification analysis of good and bruised peeled apple tissue using optical reflectance. Transactions of the ASAE. 28 (1): 326-330.

Reay, P.F. (1999): The role of low temperatures in the development of the red blush on apple fruit ('Granny Smith'). Scientia Horticulturae. 79: 113-119.

Rouse, J.W., Haas, R.H., Schell, J.A. \& Deering, D.W. (1973): Monitoring Vegetation Systems in the Great Plains with ERTS Third ERTS Symposium, NASA SP-351 I: 309-317.

Saure, M.C. (1990): External control of anthocyanin formation in apple. Scientia Horticulturae. 42: 181-218.

Sims, D.A. \& Gamon, J.A. (2002): Relationships Between Leaf Pigment Content and Spectral Reflectance Across a Wide Range of Species, Leaf Structures and Developmental Stages. Remote Sensing of Environment. 81: 337-354.

Upchurch, B.L., Affeldt, H.A., Hruschka, W.R., Norris, K.H. \& Throop, J.A. (1990): Spectrophotometric study of bruises on whole 'Red Delicious' apples. Transactions of the ASAE, 33 (2): 585-589.

Watkins, C. \& Nock, J. (2004): SmartFreshTM (1-MCP) - the good and bad as we head into the 2004 season. New York Fruit Quarterly. 12 (3): 1-26. 